\title{
Easier Done Than Said: Transnational Bribery, Norm Resonance, and the Origins of the U.S. Foreign Corrupt Practices Act*
}

\author{
Ellen Gutterman \\ Assistant Professor, Political Science \\ Glendon College, York University (Toronto) \\ egutterman@glendon.yorku.ca
}

\begin{abstract}
Paper submitted to the $84^{\text {th }}$ annual conference of the Canadian Political Science Association, 13-15 June, 2012, Edmonton, Alberta.
\end{abstract}

\begin{abstract}
The US Foreign Corrupt Practices Act of 1977 is having an unprecedented moment. In 2010, corporations paid a record $\$ 1.8$ billion in FCPA fines, penalties, and disgorgements - the most ever recorded in the first 33 years of this controversial Act's history and half of all criminal division penalties at the Justice Department. While this recent pattern of enforcement is itself interesting, a deeper puzzle lies in an examination of the origins and early trajectory of the FCPA. Throughout the late 1970s and most of the 1980s, major U.S. business groups opposed its unilateral ban on transnational bribery and lobbied the government to repeal this costly constraint on American businesses operating overseas. Yet despite a decade of pressure from otherwise powerful groups, the government failed to respond to business demands amidst strategic trade concerns about the FCPA. Why? The paper applies a Constructivist lens and concepts from the theory of legal reasoning to analyze the early history of the FCPA and explain its continued significance in US foreign economic policy. Anti-corruption norm resonance and the pressure publicly to justify norm-transgressing practices made foreign corrupt practices by American businesses "easier done than said."

* This title draws from Chapman 1998.
\end{abstract}




\section{Introduction}

The U.S. Foreign Corrupt Practices Act of 1977 (FCPA) is experiencing an unprecedented moment. In 2010, corporations paid a record $\$ 1.8$ billion in fines, penalties, and disgorgements under the FCPA, the most ever recorded in the first 33 years of this controversial Act's history, and half of all criminal division penalties paid to the United States Department of Justice. Record fines, enforcement actions against individuals, an increase in the number of civil as well as criminal actions, and strengthened enforcement of similar rules in other countries indicate a heightened emphasis by the US government on controlling foreign corrupt practices. ${ }^{1}$

While this recent pattern of enforcement is interesting in and of itself, a deeper puzzle lies in an examination of the origins and early trajectory of this legislation. Throughout the late 1970s and most of the 1980s, major U.S. business groups vociferously opposed the FCPA's criminalization of bribery in international business and lobbied the government for its repeal, or at least changes that would seriously weaken this unilateral constraint on American businesses operating overseas. Yet despite a decade of direct lobbying from otherwise powerful business groups, the government failed to respond to business concerns about the FCPA. Why? From the point of view of strategic trade theory and during an era when foreign competitors were permitted by their governments to bribe foreign officials - and write-off the cost of these bribes as taxdeductible business expenses - both the initial unilateral enactment of the FCPA and the failure of concerted attempts to repeal its "anti-competitive” provisions are deeply puzzling.

The central argument of this paper is that high public sensitivity in the United States to a norm of anti-corruption as a legacy of the Watergate scandal in the mid-1970s - conceptualized as norm resonance - made any repeal of the FCPA's anti-bribery provisions politically untenable - regardless of the material, strategic trade benefits to be gained from such a move. Specifically, government support for transnational bribery (which continued in France, Germany, and other OECD states up until the late 1990s)

\footnotetext{
${ }^{1}$ FCPA Blog, “2010 FCPA Enforcement Index.” http://www.fcpablog.com/blog/2011/1/3/2010-fcpaenforcement-index.html; see also Rubenfeld 2011; and Squire and Sanders 2012.
} 
became a policy that was “easier done than said.” (Chapman 1998). When called on to justify publicly their support for such practices, policymakers could not do so under the terms of shared norms and were thus constrained to endorse a materially costly policy.

In fact, the Act's initial enactment in 1977 was a direct product of the deeply affecting Watergate scandal. Congress passed the FCPA in the context of a heightened focus on ethics in government and in business that was part of the political fallout of the scandal. Congress intended the FCPA to ensure a high level of integrity and ethical practice among American businesses operating abroad, regardless of the opportunity costs in lost competitiveness that such a unilateral constraint would cause. In the long aftermath of Watergate, amidst increased public sensitivity to issues of corruption in business and government, repealing provisions of a law that banned bribery became “easier done than said”: They would have done it if it did not mean having to provide reasons in the course of democratic deliberation to justify and defend corrupt practices. As the chairman of the anti-corruption NGO Transparency International-USA put it, "you simply couldn't get representatives or senators to vote to repeal it ... no congressman will want to run for re-election and have his opponent say that he had voted in favor of committing bribery."2

This paper proceeds in five parts. The next section discusses the practice of transnational bribery and explains how it functions as a strategic trade policy with important material benefits for states and firms. Section three introduces the Constructivist lens and the theory of legal reasoning on which the main argument is based. Section four analyses the origins and early trajectory of the FCPA in American politics, in three steps: (i) business lobbying against the FCPA 1977-1988; (ii) a shift towards business support for international anti-bribery rules, 1994-2001; and (iii) a Constructivist analysis which explains that shift in terms of anti-corruption norm resonance during the Watergate and post-Watergate periods, from 1997 through to 2001 when the FCPA was effectively internationalized through entry into force of an international anti-bribery Convention at the OECD. This analysis highlights the underlying and lasting importance of norm resonance to any explanation of American policy on international bribery. A final section concludes the paper with some thoughts

\footnotetext{
${ }^{2}$ Fritz Heimann, Chairman of TI-USA, telephone interview by author, June 11, 2002.
} 
on the role of the FCPA in the contemporary international regime of anti-corruption and recent trends in FCPA enforcement.

\section{Transnational Bribery}

Transnational bribery is the practice of sending corrupt payments across borders from one national jurisdiction into another to secure influence in the recipient jurisdiction. While the bribery of domestic public officials has long been outlawed in the developed world, the payment of bribes across borders to foreign officials in the pursuit of international business has not. To the contrary, state support for transnational bribery of this sort was a standard practice in many OECD countries until the late 1990s. Roughly half the OECD states -- including Australia, Austria, Belgium, France, Germany, Luxembourg, Netherlands, Portugal, New Zealand, Norway, Sweden, and Switzerland -- actively condoned and endorsed such payments through measures permitting their tax-deductibility (Milliet-Einbinder 2000). While other states did not permit tax-deductibility of bribes, only a few of them explicitly prohibited it. Germany, France, and other sates that supported the tax-deductibility of transnational bribes also firmly opposed any multilateral effort to change this (George, Lacey, and Birmele 2000:496). Officials from these states argued that the bribery of public officials was a normal business practice in many countries - particularly less developed countries and paying such bribes was an acceptable practise for Western businesses engaged in commerce abroad (Brademas and Heimann 1998).

Such political support for bribery in international business reflects the fact that bribery directly implicates the material interests of states, specifically their strategic trade interests. In industries such as armaments, defence procurement, energy, heavy manufacturing, and large-scale public works and construction, domestic firms’ profits from international contracts are closely identified with the domestic national interest, both in economic competitiveness and in national security (Walzenbach 1998). States therefore extend various forms of export-financing support to those firms - including the tax deductibility of foreign bribes - as a beggar-thy-neighbour competitive strategy to help firms in these industries to win contracts. 
Not coincidentally, those economic sectors that are often identified with the “national interest” are also those in which foreign bribery is most prevalent (Transparency International 2011). Not only can the practice of bribery in foreign contract competition be cloaked in the national interest, but the nature of the contracts and projects in those sectors is such that foreign officials find them most amenable to clandestine payments. Even where the foreign government is not the counterparty, these contracts invariably require government approvals at many levels, which positions foreign officials to offer benefits in return for bribes. Moreover, these sectors involve very large projects, where payments which are meaningful to public officials are more likely to be relatively small proportions of the contract price as a whole. As well, these projects usually involve small or negligible amounts of local procurement, which facilitates the concealment of bribes to external accounts through external procurement contracts.

Another factor enabling domestic policy support for the bribery of foreign officials is an asymmetry in the cost/benefit analysis of such a policy. The national benefits of a policy supporting transnational bribery tend to be quantifiable and specific (in the form of success for national champions in international contract procurement competitions) and concentrated within important national industries. In contrast, the costs of foreign bribery - general economic inefficiency in the global economy, problems of development in the global South, the spread of illicit global financial activity — are diffuse, difficult to quantify, collective in nature and less identifiably immediate to the domestic political context. ${ }^{3}$ Therefore, a domestic cost/benefit analysis favours state support for bribery in international contract procurement, especially in economic sectors with close ties to state interests.

From the point of view of firm preferences, the use of bribery in international business transactions presents a prisoner's dilemma. Faced with a choice to bribe (or not) in pursuit of foreign contracts, every firm's dominant strategy is to bribe. If competitors bribe, then a firm will secure more contracts and higher profits by bribing than by not bribing. If competitors do not bribe, then a firm will secure even more contracts and even

\footnotetext{
${ }^{3}$ On the costs of foreign bribery, see, for example, Wei 1997; Mauro 1996; Cattan and Chaffin 2003; Transparency International, "Integrity Pact and Corruption in Public Contracting" $<$ http://www.transparency.org/integrity_pact/index.html>.
} 
higher profits by bribing than by not bribing. In particular, less efficient firms prefer bribery, as this may be their principal source of advantage in contract procurement. ${ }^{4}$ As well, even firms that are more efficient prefer to bribe rather than lose contracts to less efficient firms that bribe. Hence, the dominant strategy is to bribe.

At the same time, where two or more unscrupulous firms compete for the same contract, such competition obviously raises the cost of the contract and, ironically, the cost of the bribes themselves. In addition, if all firms bribe, the less efficient firms lose the advantage sought by the bribe. So, if none bribed, efficient firms will be better off and less efficient firms will be no worse off. This is the hallmark of a prisoner's dilemma: players have dominant strategies that yield sub-optimal results.

In light of this analysis, the unilateral U.S. Foreign Corrupt Practices Act of 1977 is especially puzzling. At a time when most states accepted bribery in the competition for foreign contracts, the FCPA was perceived to have placed American companies at a competitive disadvantage to their French, German, and British competitors, who remained unconstrained. Why did the United States unilaterally enact the 1977 FCPA in the first place?

\section{The Constructivist Lens: Norm Resonance}

Constructivist theory in International Relations (IR) posits the importance of social and ideational factors and a non-rationalist dynamic of interest formulation and interest change in explaining political outcomes. In contrast to the materialism of Realism and the instrumentalism of Rationalism, Constructivism "emphasizes the social and relational construction of what states are and what they want” (Hurd 2008:299). The Constructivist approach highlights the importance of norms and ideas in shaping international politics and foreign policy. For Constructivists, moreover, politically important norms and ideas take intersubjective and institutionalized forms. That is, they become embedded not just in the individual mind but in "collective memories,

\footnotetext{
${ }^{4}$ Where there is widespread resort to bribery in international commercial transactions, "the playing field is tilted toward unscrupulous but less efficient firms that would not fare as well in an honest system” (RoseAckerman 1997:53; see also Elliot 2002).
} 
government procedures, educational systems, and the rhetoric of statecraft” (Legro 2005:6; also cited in Hurd 2008:301).

A useful concept to consider in this context is that of a norm's resonance. Resonance is the degree to which a norm or idea engages the public imagination in a manner that activates public sensitivity within a given social context. It is a function of public sentiment and public sensitivity. Public sentiments are ideas that constrain the normative range of legitimate (publicly acceptable) solutions available to policy-makers (Campbell 1998). They are, by their nature, local and non-uniform: certain ideas resonate with higher levels of public sensitivity in some countries than in others.

In liberal democratic states, public sentiments do not need to be institutionalized in the legal system, state institutions, or government policies to constrain government's policy choices. Rather public sentiments form part of the political context in which state policies unfold. Public opinion polls, analyses of public discourse, and popular culture can reveal levels of public sensitivity to certain ideas. The challenge for Constructivism is to explain how norms and public sentiments work to shape and constrain policy-making in the international realm. While the Constructivist literature in International Relations has advanced a great deal of knowledge on this concerning global norms, much less attention has been paid to these dynamics in the literature on Foreign Policy Analysis (Houghton 2007). Interestingly, theories of legal rationality and the process of legal reasoning in the context of adjudication provide crucial insights to the workings of these mechanisms at both the international and domestic (foreign policy) levels.

The presence of a widely shared social norm can exert a force on state policy choices much as a legal precedent constrains the range of available decisions in the process of adjudication. In that process, a judge is permitted to depart from a previously established legal category or rule only if she can provide a justifiable reason for the departure. The process of legal reasoning therefore creates a “concept-sensitive strategy space” which limits the range of options that are available to decision-makers to fewer possibilities than would be suggested by preferences alone. The key idea here is that, like a legal precedent, the presence of a social norm or publicly sensitive idea can provide a social context in which policymakers find themselves obliged to give reasons for departures from the norm (that is, violations). This need to give reasons can make some 
policies harder to do: “The obligation to give reasons for a proposed move within the space of alternatives can expose some such moves as less sensible (although, perhaps, no less preferred) than others” (Chapman 1998:305). Put differently, some policies are more easily articulated and justified than others within the international social structure of norms and ideas (Campbell 1998: 295, 305). As the legal theorist Bruce Chapman has put it,

While there might be things we could 'do' if it was only a question of what we preferred, we might, nonetheless, not be able to do those things if we had to articulate a set of publicly accessible reasons, or justifications, for such a doing. After all, some things just do not bear thinking about, at least if they have to be thought about openly...they are more easily done than said (Chapman 1998:293).

This theoretical approach leads to an examination of normative features of the FCPA that are overlooked and ignored by the strategic trade analysis. In particular, a Constructivist analysis uncovers a powerful norm of anti-corruption which animates the FCPA and which operated to re-cast the acceptable limits on appropriate business practices in international commerce.

The Constructivism preferred in this study is both pragmatic and modernist (Katzenstein 1996; see also Fearon and Wendt 2002). Used chiefly as an analytic lens, it is agnostic on the ontology of international relations and loosely causal ("soft-positivist") in its epistemology. Empirically, the Constructivist theory developed here assumes that actors behave according to the "logic of appropriateness" and that preferences are endogenous to a given social interaction (March and Olsen 1998; see also Fearon and Wendt 2002: 54-5). Accordingly, the argument elaborated below is that some policies are more easily articulated and justified than others within the international - or in the case of foreign policy analysis, domestic - social structure of norms and ideas (Chapman 1998: 295, 301). Where action requires justification, therefore, the obligation to give reasons for choices makes some things hard to do. In the case of the FCPA policy makers found that, due to the resonance of the anti-corruption norm in American politics, they could not openly justify state support for bribery in international business, regardless of the strategic trade incentives which otherwise would have led them to do so. 


\section{The Foreign Corrupt Practices Act: Origins and Trajectory of a Once Controversial Law}

In 1977 the Foreign Corrupt Practices Act outlawed the bribery of foreign public officials in international business transactions, through two sets of provisions. First, criminal law provisions under the jurisdiction of the Justice Department made it a criminal offense for any U.S. person (individual or corporation) to make payments to foreign government officials to assist in retaining or obtaining business. Second, accounting and reporting provisions of the Act, under the jurisdiction of the Securities and Exchange Commission introduced record-keeping rules designed to further deter and punish such unlawful payments. Criminal penalties under the act included fines of up to $\$ 2$ million dollars for firms, and up to $\$ 100,000$ and five years imprisonment for individuals.

\section{Business Lobbying Against the FCPA: 1977-1988}

From the time of its introduction in 1977 and throughout the 1980s, major U.S. corporations, manufacturers' lobbyists, and exporter groups opposed the Foreign Corrupt Practices Act's unilateral constraints on American companies operating overseas. These critics objected to the Act on four grounds. First, they argued that the Act's prohibition of "questionable" payments in foreign jurisdictions represented an unacceptable effort to impose American morality on other states and foreign actors (Salbu 1997; see also Pastin and Hooker 1984). They pointed to the lack of a global consensus on the ethics of questionable payments, arguing that bribery is a cultural construct and the matter of deciding when payments are "corrupt" is best left to the discretion of local officials. Second, critics argued that the FCPA caused U.S. companies to lose business and thus contribute to the expanding U.S. trade deficit. They argued further that a unilateral U.S. prohibition on foreign bribery was foolhardy and a multilateral approach leading to an international agreement was needed (GAO 1981). Finally, and related to their contention that the FCPA's undue constraints on business operations were costly to the trade deficit, American corporations argued that the FCPA was a deeply flawed, ambiguous piece of 
legislation, and its difficulty of interpretation and onerous accounting requirements was causing many U.S. companies to abandon international business opportunities.

In view of such objections, it was not surprising that the FCPA became, as soon as it was passed in 1977, “a major source of controversy” among government officials and U.S. businesses seeking major amendments (Morgan 1979). As one member of the House of Representatives put it in 1979, “[t]he Foreign Corrupt Practices Act has had a history of attempts to undermine its effectiveness, even before it was passed.”5

As early as September 1978 fierce opposition caused the Carter administration to yield somewhat to business concerns about the FCPA; the President promised that the Justice Department would “issue guidance” to U.S. companies to clarify its enforcement policy. This move, however, failed to mollify critics. In March 1979 the Washington Post reported: "Dozens of American businessmen interviewed around the world said they now feel at a disadvantage working in countries where extortion and corruption by foreign officials is commonplace” (Morgan 1979).

During this same period, the Carter administration undertook a comprehensive review of its export promotion programs. As a result, a special White House Export Disincentive Task Force concluded that overseas bribes can be an export incentive and that the FCPA, by barring U.S. companies from partaking in this incentive practice, cost the United States \$1 billion per year in lost trade. In a draft report produced for the White House the Task Force presented recommendations for offsetting this $\$ 1$ billion loss, including "gutting” the FCPA and removing enforcement power from the Securities Exchange Commission (SEC) (Kramer 1979).

This draft report was leaked to the press in June 1979. Proponents of the FCPA within the SEC and the Justice Department blamed the task force for submitting to pressure from U.S. companies. SEC and Justice officials said that "much of the draft proposal reflected intense lobbying on the White House and the Commerce Department by businessmen seeking to undermine the bribery law” (Quoted in Kramer 1979). Continued public and private criticism of the proposals to diminish the FCPA's impact on corporate practices, led mainly by Democrats in the House of Representatives, ultimately

\footnotetext{
${ }^{5}$ Rep. Bob Eckhardt, speaking at a House Commerce subcommittee hearing on June 14, 1979, quoted in Kramer 1979.
} 
caused the task force to abandon its specific recommendations. A Washington Post report noted:

A White House study group is having second thoughts about making a proposal that would legalize some overseas bribery by U.S. corporations, even if the action were designed to foster U.S. trade overseas (Kramer 1979).

When the President's export council produced its final recommendations, however, they did not neglect the FCPA. The task force recommendations included a series of steps aimed at improving the trade balance, such as increasing the "exportconsciousness" of the nation, strengthening the federal government's role in international trade functions, reducing barriers to foreign trade, improving export incentives, and eliminating or reducing export disincentives. Among these latter were listed "laws and policies which unreasonably or unnecessarily operate as unilateral, self-imposed disincentives on U.S. export" and which should be eliminated or "administered more reasonably.” One law specifically listed in this category was the Foreign Corrupt Practices Act. ${ }^{6}$

In November 1980 Ronald Reagan defeated Jimmy Carter in a landslide electoral victory with his legendary promise to Americans to "get government off your backs." Among the Reagan administration's first orders of business in early 1981 was a response to ongoing complaints by American companies about the FCPA. In March 1981 the General Accounting Office (GAO) of the White House produced a report stating that "55 percent of the largest industrial firms polled opposed the act's accounting and antibribery provisions (or at least that these cost them business.) (Hamilton 1981a)”. The GAO thus recommended to Congress that it significantly amend the FCPA, to the extent of repealing some of its criminal provisions; the GAO advised that Congress, the SEC and Justice should “meet business community objections to the act” (Hamilton 1981a; see also GAO 1981). United States Trade Representative Bill Brock subsequently supported these recommendations in an outspoken op-ed column published in the Washington Post,

\footnotetext{
${ }^{6}$ Alongside the FCPA the report also categorized as export disincentives such policies as taxation of Americans working overseas, extra-territorial application of U.S. anti-trust laws, U.S. anti-boycott laws, and export controls. See Seringhaus and Rosson 1990, 57-59, where the following reports are cited: U.S. Department of Commerce, Report of the President on Export Promotion Functions and Potential Export Disincentives, US GPO, 1980; and U.S. Department of Commerce, The Export Imperative, Report to the President submitted by the President's Export Council, December 1980, vol. I. Discussion of FCPA in the latter document, pp. 17-18.
} 
and Senator John Chafee proposed a bill in Congress to amend the FCPA in tune with the wishes of the Reagan administration and the business community (Brock 1981; see also Hamilton 1981b). The Chafee Bill, S-708, proposed to eliminate the FCPA's "reason to know” provisions (forbidding payments to an agent if one has a reason to know that the payment might be used to bribe a foreign official); to reduce the burden of corporate record-keeping from the standard of "reasonable detail" to require only information that is "material"; and to remove the enforcement purview of the SEC. Senator William Proxmire, the originator of the 1977 Act, called the Chafee Bill "a slug through the heart of the FCPA" (Hamilton 1981b). ${ }^{7}$

Other opponents of the proposed amendments concurred, arguing that under the guise of clarification of "alleged ambiguities of the statute and uncertainties about interpretations”8 the Chafee amendments would so hamper enforcement of the FCPA that the Senate might as well just repeal all of the FCPA's anti-bribery provisions. Former SEC Chairman Harold Williams, for instance, was particularly concerned about two aspects of the proposed amendments. First, whereas the original Act required that corporations to a "reasonable degree” keep “accurate and fair” records and internal controls, the Chafee Bill's imposition of a materiality standard for reporting — set at a dollar threshold — would allow big expenditures in large corporations to go totally unreported. Williams' second concern was that the bill's proposal to remove the provision that made corporations and officials liable when they had "reason to know" when a bribe was being paid would make the legislation virtually toothless. Instead of these changes, argued Williams, "I would rather have the antibribery provisions repealed." 9

Though stopping short of direct proposals for actual repeal, ample evidence suggests that a loosening of both the FCPA's accounting and anti-bribery provisions to a point effectively similar to repeal was exactly what business opponents of the Act would have preferred. Pursuing this end, a number of prominent corporate executives and

\footnotetext{
${ }^{7}$ Proxmire also publicly challenged the assertion that the FCPA cost U.S. businesses in the first place, arguing: "Experience has shown that the law has curbed bribery without harming export sales" (Proxmire 1981).

${ }^{8}$ Carter administration official, quoted in Heymann 1981.

${ }^{9}$ Hamilton 1981e reports comments by Williams to the Senate Banking Committee.
} 
representatives of major industry groups testified in senate committee hearings in support of the Chafee Bill (U.S. Senate 1981). These included representatives of the National Small Business Association, the Emergency Committee for American Trade (an organization of 63 large firms with extensive overseas operations), and the National Association of Manufacturers. Representing the views of the latter, in particular, an executive of Ingersoll Rand - at that time a \$3 billion producer of industrial machinery - asked Congress in his testimony to grant the President power to suspend the FCPA's antibribery provisions (Hamilton 1981c).

On September 16, 1981 the Senate Banking, Housing, and Urban Affairs Committee reported the Chafee Bill and approved the following amendments to the FCPA: renaming the legislation the Business Practices and Records Act; eliminating the "reason to know" language; making it unlawful to direct or authorize a third party to bribe “expressly or by course of conduct”; consolidating enforcement in the Justice Department, i.e. removing the SEC from its enforcement role; and including a “costbenefit" test that "allows businesses to weigh the costs of beefing up mandated accounting controls against the prospective benefits.” According to a report in the Washington Post, "business officials [had] avidly sought both the cost-benefit test for the accounting controls and the change in the 'reason to know' language” (Hamilton 1981f; the reported bill did not include the materiality for reporting). The Chafee amendments to the FCPA passed in a voice vote in the senate on November 23, 1981. The Washington Post reported: “The Senate voted yesterday to soften the provisions of the FCPA because American firms claimed they have been losing business abroad as result of the law” (Berry 1981).

The Chafee Bill became the subject of legislative controversy in Congress for the next seven years; despite continued support from business groups, however, it did not survive. First, House Representatives hotly debated proposed FCPA amendments based on the Senate's bill. Representative Daniel Mica proposed amending the FCPA along the same lines, as part of the Export Administration Act being put together by the House Foreign Affairs subcommittee on international economic policy and trade (relating to limits on export of high technology to the Soviet Union) (Auerbach 1983). However, Representative Timothy Wirth, chairman of the House Energy and Commerce 
subcommittee - which held four days of hearings on proposed changes to the FCPA opposed such proposals and would not report the bill to the floor (Auerbach 1983). Observers noted that "Mica's move, effectively transferring jurisdiction to the House Foreign Affairs Committee, is an attempt to break the legislative logjam” (Auerbach 1983).

The jurisdictional dispute persisted. The House Foreign Affairs Committee finally approved a widely supported trade bill in April 1986. Attached was an amendment proposing changes to the FCPA. Backed by a coalition of major business groups, including the Chamber of Commerce of the United States, the National Association of Manufacturers, the Business Roundtable, and the Emergency Committee for American Trade, that amendment had originally been sponsored by Representative Mica as a separate bill. Opponents of the FCPA amendments immediately tried to block the legislation. Representative John Dingell asked the House Speaker to send the legislative proposal to the House Energy and Commerce Committee (which he chaired) because it — and not the Foreign Affairs Committee — had proper jurisdiction over the FCPA (United Press International 1986).

In June 1986 tension over trade policy reached a peak in the government. The Reagan White House moved to block a major House trade bill, which it considered too protectionist. Critics of the White House argued, however, that the executive branch was not doing enough to control the record trade deficit ( $\$ 148.5$ billion in 1985) and that Congress seemed to be the only branch of government ready to step in. Major business groups did not back Reagan's efforts to block the trade bill; rather, they supported measures in the bill that would weaken the FCPA, which they continued to argue shielded competitors who used unfair trade practices (Auerbach 1983; see also United Press International 1986).

In October 1987, a major House-Senate conference tried to develop one piece of trade legislation out of different bills produced by the House and the Senate. Among the bills on which the Congressional panel struggled to work out a compromise were proposed changes to the FCPA. The Senate and the House had passed "starkly different amendments": the Senate's amendments to the FCPA, based on the Chafee Bill of 1981, were designed to "lighten the burden on business" in response to the demands of business 
groups, while the House had approved measures to "clarify and strengthen” the Act (Mintz 1987). At the same time, six major business organizations got together to set out their views on the bills. Calling themselves the Business Coalition on Trade and purporting to "represent the mainstream of U.S. business," they endorsed six major provisions, including amending the FCPA to relax its constraints on American businesses (Auerbach 1987). ${ }^{10}$

In November 1987, Democrats won control of both the House and the Senate. In March 1988, Congressional conferees finally hammered out a compromise on changes to the FCPA, in which the House proposals won out over the Chafee Bill that had been supported by business-group lobbyists and the Reagan administration (Mintz 1988). These amendments became part of the U.S. Omnibus Trade and Competitiveness Act of 1988.

The 1988 FCPA amendments made changes to both the Act's accounting provisions and its anti-bribery provisions. Although some critics argued that the changes effectively "killed” the legislation (Lissakers 1988; for a detailed review see Brennan 1990), the amendments stopped short of several of the demands made over the previous decade by U.S. businesses (and by the Reagan administration), and indeed stopped short of the Chafee Bill. For instance, while business groups had lobbied for a decriminalization of the Act's accounting provisions, together with a repeal of the SEC's enforcement power, the 1988 amendments instead retained the joint enforcement jurisdiction of the SEC and Department of Justice. The amendments also responded to business concerns about ambiguity surrounding enforcement of the Act by codifying the SEC's existing policy on criminal prosecutions of accounting failures; these would be restricted to situations of deliberate ("knowing”) circumvention or failure to implement control systems. In other words, criminal prosecutions would continue but would not be initiated for negligence or technical violations.

In addition, the 1988 amendments clarified the terms "reasonable detail” and “reasonable assurances” in the Act's accounting and record-keeping requirements to mean that which would be "reasonable to a prudent person." The amendments did not

\footnotetext{
${ }^{10}$ The Business Coalition on Trade was comprised of the following groups: The Business Roundtable, Emergency Committee for American Trade, National Association of Manufacturers, National Foreign Trade Council, U.S. Chamber of Commerce, and U.S. Council for International Business.
} 
adopt the "materiality” standard for which businesses had lobbied hard. They did, however, follow business demands in replacing the "reason to know" standard in the antibribery provisions with a "knowing” standard, but also included language explicitly prohibiting the "head in the sand" approach that opponents of the Chafee Bill had worried would ensue from such a change.

Congress added a new section to the 1988 amendments indicating its intent that the President should negotiate an agreement with the OECD to internationalize the antibribery norms of the FCPA. This new language further required the President to report to Congress on the progress of negotiations and any steps taken should such negotiations fail. This responded specifically to business concerns that the FCPA's unilateral approach harmed U.S. economic interests. But it did not include the provision requested by some lobbyists that the President be permitted to suspend the FCPA's anti-bribery provisions in the event that international negotiations failed to produce an agreement on foreign bribes.

In sum, though some critics argued that the 1988 amendments rendered the FCPA toothless, the changes stopped far short of almost all the amendments that the businesses lobby had promoted. Furthermore, even these watered-down amendments had proved extremely difficult to achieve. It had taken "an extraordinary eight year effort by some members of Congress and some business lobbyists” to produce any amendments whatsoever, and ultimately these could only pass as part of the huge omnibus trade legislation (Brennan 1990:229). In fact, a Washington Post report noted that "[1]argely because the amendments were part of the omnibus trade bill, which has immense implications for the domestic and world economies, they created few ripples off Capitol Hill” (Mintz 1987) Brennan concurred with this view in his retrospective analysis of the amendments:

The 1988 FCPA amendments are only six pages in this approximately four hundred page piece of legislation whose goals only indirectly, at best, were to amend the FCPA. Those seeking to amend the FCPA had, over an eight year period, failed to obtain passage of such amendments when they were introduced as separate bills (Brennan 1990:229).

It is also important to note that, despite opposition to the amendments by supporters of the FCPA as originally enacted in 1977, Cragg and Woof maintain that "[a]lthough these changes restricted the scope of the FCPA, the actual number of 
potential FCPA cases investigated increased after passage of the Omnibus Trade Act, in part because the amendments defined more clearly the legal obligations of corporations” (Cragg and Woof 2001:187).

\section{Business Support for Anti-Bribery Rules: 1994-2001}

Despite a decade of lobbying for changes that would significantly weaken the effectiveness of the FCPA in unilaterally controlling foreign corrupt practices by American companies operating overseas, businesses after 1988 were left with an FCPA that was very much alive. At the same time, the 1988 amendments introduced a new legacy: a renewed, mandated effort on the part of the U.S. administration to internationalize the FCPA through the OECD. From at least 1994 U.S. businesses strongly supported this effort. It is a neat parallel that ten years after the passage of the U.S. Omnibus Trade and Competitiveness Act, almost all the same business groups that once actively lobbied against the 1977 FCPA now lobbied just as ardently in favour of the nascent OECD anti-bribery Convention, which ultimately was signed in 1997. These groups expressed their views to Congress both via the U.S. branch of the international anti-corruption NGO Transparency International, TI-USA, and in several open letters to the Senate Committee on Foreign Relations. One of their key demands was for the U.S. to be among the first OECD member states to demonstrate full compliance with the new Convention.

For example, the CEOs of 35 major corporations signed a letter to Senator Sarbanes to express their "support for the speedy ratification and implementation of" the 1997 OECD Convention, noting:

The OECD Convention is a major victory for the United States in its battle against international corruption and bribery ... Speedy ratification and implementation of the OECD Convention by the United States is, however, an absolute imperative in order for the Convention to succeed. Some of the other parties are not as committed to the Convention as the United States and are likely to use a delay in US ratification to undermine it. Speedy implementation of the OECD Convention is also necessary to show the other parties that the United States takes its obligations under the Convention seriously and expects other parties to do the same. Since the Convention's effectiveness depends on the adoption of international anti-bribery laws by other parties, implementation by the United States is necessary to lead the way, substantively and politically, for 
implementation by other parties ... We are committed to working with you to help protect US businesses and workers from unfair and corrupt foreign competition through the ratification and implementation of the OECD AntiBribery Convention by the Congress this year. ${ }^{11}$

As part of his testimony to the Senate committee, the Chairman of TI-USA Fritz Heimann underlined the business community's support for the Convention as follows:

The Convention has the overwhelming support of a broad coalition of major business organizations, including the Business Roundtable, the US Council on International Business, the National Foreign Trade Council, the National Association of Manufacturers, and the Emergency Committee for American Trade. $^{12}$

In general, the Convention met with wide acclaim in American political and business circles (Blustein 1997b; Goldschlager 1997; Marcuss and Goldschlager 1997; Washington Post (Op-ed) 1998).

This shift in policy preference on foreign corrupt business practices by U.S. corporations is readily explained as a rational response to their previous failure to change American policy. No explanation beyond that provided by material, strategic trade interests and a rational-choice analysis is necessary to account for this shift. However, what this explanation does not readily explain is the failure of the 1980s lobbying effort that made the observed shift in policy preference a rational strategy for U.S. business interests. While U.S. government and business policies on foreign bribery and corruption have been rational given the strategic trading circumstances, the current analysis highlights the backdrop of the Foreign Corrupt Practices Act as the key to explaining the course of U.S. policy on this issue.

\footnotetext{
${ }^{11}$ Letter dated May 28, 1998 to Senator Paul S. Sarbanes and signed by CEOs of 35 major U.S. corporations. Included in Senate Executive report 105-19, p. 36-7. The complete list of signing companies is: ABB Inc.; AlliedSignal, Inc.; AMP Incorporated; Bethlehem Steel Corporation; Caterpillar Inc.; Chrysler Corporation; Digital Equipment Corporation; DuPont Company; Foster Wheeler Corporation; Honeywell, Inc.; ITT Industries, Inc.; Mentor Automotive, Inc.; Raytheon Company; Tenneco; Textron Incorporated; The Perkin-Elmer Corporation; United Parcel Service of America; Westvaco; Air Products and Chemicals, Inc.; American International Group, Inc.; AT\&T; Cargill, Inc.; CBS Corporation; CSX Corporation; Dresser Industries, Inc.; Eastman Kodak Company; General Electric Company; IngersollRand Company; Merck \& Company, Inc.; Phillips Petroleum Company; Rockwell International Corporation; Texas Instruments Incorporated; The Boeing Company; TRW, Inc.; United Technologies Corporation.

${ }^{12}$ Fritz Heimann, June 9, 1998 in Senate Executive Report 105-19.
} 
A rationalist analysis can accommodate government lobbying by American corporations in the 1990s for prompt and full compliance with the OECD Convention as an adaptive response to their failure in the 1980s to repeal the FCPA's anti-bribery provisions. Once it became clear that these provisions - a serious constraint on competition with foreign corporations at liberty to use bribes to procure major contracts - would remain a fixture of U.S. corporate regulations, business shifted its emphasis to internationalizing the American rules with the aim of "leveling the playing field" upwards to the level of U.S. regulations. This is clear. Yet, left unexplained by the strategic trade analysis is the reason why US corporations - and an influential group of senators and Reagan White House officials - had such difficulty in their attempts to amend the FCPA.

The next section explains this puzzle in terms of the high resonance of the anticorruption norm in the domestic political context that resulted from the Watergate scandal in the 1970s, a norm context that coloured political efforts to amend the FCPA throughout the 1980s.

\section{Explaining the Shift, 1977-2001: Anti-Corruption Norm Resonance in American Politics}

Corruption and scandal have always been a feature of American political life (Williams 1995, 2003; see also Roberts and Doss 1997). In the last third of the twentieth century, however, the issue of corruption in American politics began to receive much greater public attention than ever before. Opinion poll evidence suggests, further, that public trust in the integrity of politicians also fell sharply during this period (Williams 1998). The turning point was the Watergate scandal of the early 1970s, the wide-ranging effects of which served to elevate the issue of corruption on the political agenda (Williams 2003; Mackenzie 2002). Indeed, the Watergate scandal was a "pivotal event in American political history in many ways” (Mackenzie 2002). ${ }^{13}$

\footnotetext{
${ }^{13}$ According to Williams, moreover, it was a "defining event" that marked the end of an era of "optimism, self-confidence, and trust in government” (Williams 1998:9).
} 
It is in the context of Watergate and post-Watergate American politics that the FCPA and U.S. policy towards international bribery and corruption in general must be understood. The FCPA was enacted as a direct result of shocking Watergate-related revelations about foreign corrupt practices employed by major U.S. corporations. It was the ethical resonance of these revelations that led legislators to enact the FCPA, regardless of important countervailing material strategic trade considerations.

Subsequent efforts to repeal or amend the FCPA, moreover, were impeded by the long-lasting resonance in American politics of the international norm of anti-corruption that was first articulated in the FCPA following Watergate. Despite important material strategic trade reasons to do so, no repeal of the FCPA could succeed in a climate coloured by the norm of anti-corruption. Even the project to amend the Act, short of repeal, faced difficulty due to the "touchy" matter of foreign bribery and corruption. Once the FCPA was in place, any policy designed to retreat from its standard would have been "easier done than said." Ultimately, this was the context for the U.S. push for internationalization of its FCPA at the OECD, and within which even contemporary U.S. enforcement of the FCPA is to be understood.

\section{The Watergate Scandal}

The Watergate scandal emerged two days before Richard Nixon's landslide presidential re-election in October 1972, when a congressional committee made public its discovery of secret receipts collected by the Nixon campaign, including $\$ 30,000$ in indirect contributions from a prominent U.S. defence contractor (Neild 2002). The response of administration officials at the highest levels was to initiate an extensive cover-up operation. Eventual disclosures about the cover-up to a grand jury spurred a series of further investigations by a succession of citizens' groups and government bodies, including the public interest group Common Cause, the Senate Watergate Committee chaired by Sam Irwin, the Justice Department, the Watergate special prosecutor, and the SEC. ${ }^{14}$

\footnotetext{
${ }^{14}$ For a detailed account of the history of Watergate, see Emery 1994.
} 
In addition to the now infamous burglary of the Democratic Party headquarters in Washington's Watergate building and the President's attempts to cover it up, these investigations revealed illicit links between some of America's biggest corporations and the Nixon White House, including a secret multi-million dollar fund to finance the coverup (Boulton 1978:253). In particular, Nixon's Committee to Re-Elect the President (CREEP) had solicited illegal campaign contributions in 1972 from such major companies as Northrop, Gulf, Goodyear, and others, for the express purpose of paying off the Watergate burglars and ensuring their cooperation in the conspiracy.

Concurrent with the Watergate investigation, a Senate sub-committee on multinational corporations, chaired by Frank Church, also uncovered in its hearings a startling revelation of large-scale, systematic corporate bribery and corruption abroad particularly by the American oil companies Gulf, Exxon, and Mobil. ${ }^{15}$ Originally convened in 1972 to follow up on disclosures of U.S. corporate interventions in Chile and to investigate the extent of U.S. corporations' influence on foreign policy, the Church committee expanded its mandate in 1973 to investigate the questionable corporate practices that were coming to light as a result of the Watergate investigations.

Other government agencies proceeded with inquiries of their own. The Senate Committee on Banking, Housing, and Urban Affairs, chaired by William Proxmire, held extensive hearings on the matter of improper payments to foreign government officials by U.S. corporations and also revealed widespread use of foreign bribery. At the SEC, Stanley Sporkin, head of the commission's enforcement division, devised a voluntary disclosure program in which each of the companies on CREEP's register of illegal contributors "agreed to investigate itself and deliver its detailed findings to the SEC and the courts” (Boulton 1978:257). As a result of this program, between 1974 and 1976 approximately 435 American corporations voluntarily disclosed to the SEC that they had made improper or questionable payments totaling more than $\$ 300$ million to foreign officials or members of foreign political parties (Cragg and Woof 2001). Moreover, they

\footnotetext{
${ }^{15}$ In 1972, reports surfaced that, two years previously, the International Telephone and Telegraph Corporation (ITT) had sought to influence the CIA with a \$1 million payment to intervene against the imminent election of Salvador Allende. The Senate Committee on Foreign Relations convened the SubCommittee on Multinational Corporations to investigate these reports.
} 
had kept these payments off the books and maintained secret currency slush funds for that purpose.

Various officials subsequently testified about these disclosures to the SEC in hearings before Senator Church’s committee, which in 1975 moved from its focus on oil companies to the defense industry, opening hearings on Northrop and, most notably, the Lockheed Corporation, at that time the biggest private defense contractor in the world (Boulton 1978). These hearings, in turn, uncovered a long history of corporate bribery, kickbacks, payoffs, and otherwise "questionable payments" in the hundreds of millions of dollars to foreign public officials. Among the revelations, the Lockheed Corporation alone admitted paying at least \$22 million in bribes to foreign officials and foreign political organizations; at least \$106 million in commissions to the arms trade middleman Adnan Kashoggi (who was also being paid by Northrop at the same time); at least \$1 million to Prince Bernhard of the Netherlands in connection with a Dutch government purchase of Lockheed Starfighter jets; \$12 million dollars to Franz-Josef Strauss, the Minister of Defence of West Germany, also in connection with a Starfighter purchase; and several multimillion dollar payments to a shadowy network of Japanese officials in connection with a deal to sell Tristar civilian airliners, including \$1.7 million to Japan’s Prime Minister Tanaka (Neild 2002). These ongoing disclosures had vast international repercussions and resulted in scandals that led to the downfall of governments and officials in Japan, the Netherlands, and Korea (U.S. House of Representatives 1977; see also U.S. Senate 1977; and Noonan 1984:652-680).

As a result of these various investigations and revelations, a broad consensus emerged in Congress that "foreign bribery is a reprehensible activity and that action must be taken to proscribe it” (U.S. House of Representatives 1977). Senator Proxmire, accordingly, sponsored a bill to criminalize the bribery of foreign public officials. In 1977 the US Foreign Corrupt Practices Act passed following relatively little debate; the legislative process took less than one year amidst a "tone of moral outrage and the urgency of moral reform” that, according to Cragg and Woof, “would constitute a major theme of the Carter Administration” (Cragg and Woof 2001:187; see also Longbardi 1987). 
In opting to criminalize foreign bribery, the U.S. government took the strongest possible stance against corrupt practices, leaving no doubt that the government considered these practices "unethical" and "counter to the moral expectations and values of the American public.” ${ }^{16}$ The government also argued that foreign corporate bribery tarnished the image of American democracy abroad, impaired confidence in the financial integrity of American corporations, and hampered the efficient functioning of U.S. capital markets (U.S. Senate 1977). In sum, in addition to being unethical, Congress considered foreign corporate bribery to be

bad business ... It erodes public confidence in the integrity of the free market system. It short-circuits the marketplace by directing business to those companies too inefficient to compete in terms of price, quality or service, or too lazy to engage in honest salesmanship, or too intent upon unloading marginal products. In short, it rewards corruption instead of efficiency and puts pressure on ethical enterprises to lower their standards or risk losing business (U.S. House of Representatives 1977).

Using similar words on the ethical imperative of the FCPA, Senator Proxmire noted:

Bribery is simply unethical. It is counter to the moral expectations and values of the American public, and it erodes public confidence in the integrity of the free market system. Bribery of foreign public officials by some US companies casts a shadow on all US companies. It puts pressure on ethical enterprises to lower their standards and match corrupt payments, or risk losing business...(U.S. Senate 1976:1). ${ }^{17}$

Despite concerns that a unilateral American ban on foreign bribery in international business would hamper the competitiveness of American companies operating overseas, when Congress debated the passage of the Act the potential loss of business contracts was considered and rejected as a rationale against the FCPA. The decision was considered a trade-off between "economics” and "morals.” As put by Agnieszka Klich, “Congress decided that U.S. companies should be at a competitive

\footnotetext{
${ }^{16}$ Congress initially considered two possible approaches for curbing the type of bribery payments defined in the FCPA. One was to require these payments to be publicly disclosed and criminal penalties imposed for failure to disclose. The other approach was to outlaw the payoffs with criminal sanctions. Congress opted for the second, stronger approach — to criminalize bribery.

See U.S. House of Representatives, 95th Congress, Unlawful Corporate Payments Act of 1977, Report No. 95-640, September 28, 1977; also Lashbrooke 1979:232.

${ }^{17}$ Also quoted in Cragg and Woof 2001:193. The discussion in Cragg and Woof emphasizes the imperatives of U.S. foreign policy in the origins of the FCPA, as well, since Proxmire went on to add, "Bribery by U.S. companies also undermines the foreign policy objectives of the United States to promote democratically accountable governments and professionalized civil services in developing countries.”
} 
disadvantage if their only means of competing is through the payment of bribes” (Klich 1996:142).

Opponents of the Act immediately recognized the political impact of the context in which the FCPA was originally passed. Writing to the Washington Post to urge extensive amendments to the FCPA in 1981, U.S. Trade Representative Bill Brock acknowledged that the Act, which he considered a disincentive to trade, had started out with "good and noble intentions" and even that "there was something courageous and typically American in Congress’ efforts to prohibit corporate bribery overseas” (Brock 1981). Brock considered the enactment of the FCPA a mistake, an over-reaction to the Watergate revelations that had made it politically untenable for any Congressman to oppose the FCPA in the first place. According to Brock,

Congress reacted quickly and emotionally to daily newspaper headlines and public outcry ... With members of Congress, the administration and the business community all unwilling to challenge a draft of the law for fear of being accused of favoring bribery, the bill sailed through Congress by unanimous vote and was signed into law in December 1977 (Brock 1981).

\section{Post-Watergate Politics: The Resonance of the Norm of Anti-Corruption}

The aftermath of Watergate produced wide-ranging attempts to regulate and control corruption in American political and economic life. In addition to the FCPA, Congress enacted amendments to the Federal Election Campaign Act and introduced the 1978 Ethics in Government Act. Each would prove to have a lasting and important impact on the course of American politics. ${ }^{18}$ During this period the FBI also began to make the investigation of corruption one of its most important priorities (Williams 2003).

Numerous scholars have noted that a lasting effect of Watergate on American political life has been a tendency to "overreact to corruption scandals by introducing ever more onerous and rigorous” anti-corruption laws (Williams 2003; Mackenzie 2002;

Roberts and Doss 1997). As a result, a "low threshold of unethical conduct" has become a distinctive feature of American politics, in which corruption is a highly salient political

\footnotetext{
${ }^{18}$ The U.S. Ethics in Government Act established an Office of Government Ethics to oversee disclosure statements required of senior members of the executive, and created the office of the Independent Counsel, responsible for the criminal investigation and prosecution of senior executive officials, including the President. Investigations by this office would later dog Bill Clinton throughout his Presidency, especially during the Monica Lewinsky affair. See discussion in Neild 2002:150.
} 
issue (Williams 2003:73-78). Calvin Mackenzie has described this as a "post-Watergate mentality"; Robert Roberts and Marion Doss have called it “the nation’s morbid postWatergate preoccupation with government ethics,” consisting primarily of societal suspicion of all public servants, combined with a perceived need to legislate public ethics rules (Mackenzie 2002:31; Roberts and Doss 1997:xv).

Scholars have explained this deep preoccupation as the consequence of an overwrought media, an abiding lack of trust in government that is a holdover from the Vietnam era counterculture, the push by public interest groups, especially Common Cause, for good government and reform, and the breakdown of governing institutions that has led to partisan use of corruption allegations to immobilize opponents (Roberts and Doss 1997: xv-xx; see also Sabato 1991; Garment 1991; and Ginsberg 1999). Whatever their explanation, analysts concur that in post-Watergate American politics, ethics has become "the motherhood issue of its time." No politician wants to be "on the side of less ethics” (Mackenzie 2002:34). In short:

The response to Watergate was a powerful political force that built on all that came before Watergate. And what it ultimately produced was an array of ethics laws, rules, and procedures that had no precedent in the United States or in any other country in the history of the world (Mackenzie 2003:35).

The effects of this post-Watergate mentality proved especially trying to the Reagan administration during the 1980s. Because of increased public and institutional scrutiny, the administration was plagued by unprecedented allegations and investigations into corruption among its high-ranking officials. For instance, the President's National Security Advisor, Richard Allen, was forced to resign in January, 1982 — barely a year after Reagan took office - following charges of improperly accepting gifts from a group of Japanese journalists (Williams 1995). Three other administration officials resigned in 1984: Attorney General William French Smith, amidst allegations of tax evasion; Deputy Secretary of Defense Paul Thayer, when the SEC brought charges of insider trading; and Secretary of Labor Raymond Donovan, who was indicted on criminal charges of fraud and forgery (Donovan was later acquitted of these charges in 1987). Reagan's first-term deputy chief of staff in the White House, Michael Deaver, was convicted in 1987 of lying to Congress and to a grand jury about his contacts as a lobbyist following his departure 
from office in 1985. In 1988, Attorney General Edwin Meese, along with several senior staff at the Justice Department, resigned amidst persistent allegations of misconduct involving bank loans and reciprocal favors (Williams 1995).

It was in this context of public distrust that the Reagan administration and Congress sought to amend the Foreign Corrupt Practices Act. Because of heightened public sensitivity to ethics in business and in government, amending the Act proved to be politically delicate and, indeed, "easier done than said." Administration officials and members of Congress found it difficult to justify their calls for amendments that would weaken (or appear to weaken) the FCPA. As Bill Brock noted at the time about the controversial proposals to amend the FCPA, “[I]t's difficult to bring up in casual conversation; politically it’s a hot potato” (Brock 1981).

Advocates on both side of the debate surrounding the proposed FCPA amendments noted the politically delicate nature of the Act's subject matter. Those who supported amending the FCPA lamented the political difficulties they faced. Rod Hills, a former SEC Chairman, noted, for example: "If we looked at it [the Chafee bill] as a cleansing process rather than a repeal, I think that we could approach the amendments with a lot less heat" (U.S. Senate 1981).

Senator Chafee, the sponsor of the bill to amend the FCPA in line with business concerns, felt it necessary during his committee's hearings on the matter to defend himself repeatedly against any potential allegation that in proposing the amendments he supported bribery, noting for instance:

I think that should be made very clear. The point we're trying to make is not that we are condoning bribery, or seeking to go back to bribery. We are trying to make the act more effective, achieve its goals at the same time we try to make clearer what the act stands for, and remove ...'the anxieties' (U.S. Senate 1981).

In a similar vein, Chafee commended the business representatives who came forward in support of the proposed amendments, despite the potential harm to their reputations. Chafee acknowledged:

This act that I have undertaken to change is looked on as motherhood, and I respect each of you for coming forward today because obviously the changes we have made in this act don't connote bribery. What they try to do is create an act that makes sense (U.S. Senate 1981). 
Indeed, the business representatives who spoke in support of the Chafee proposal tried in their statements to distance themselves from the appearance of condoning bribery. For example, one business executive noted:

Before I begin my comments, I would like to state for the record, Enserch Corp. is not in favor of bribery. It is a sad commentary on the political atmosphere surrounding this legislation that those who support the bill feel compelled to make clear that they do not condone corruption (U.S. Senate 1981).

At the same time, opponents of the 1981 Chafee bill skewered the proponents of reform for focusing their criticisms on alleged ambiguities in the FCPA's language. One former Carter administration official noted in his opposition to the Chafee amendments that the debate on the bill had centred on alleged ambiguities of the statute and uncertainties about interpretations because, in his words, "[t]his has protected politicians and businessmen from having to defend corruption...Practically no politician or businessman will openly defend bribery of officials, even abroad” (Heymann 1981).

Just as it was impolitic to oppose the FCPA throughout the 1980s, supporting the OECD Convention in the late 1990s proved to be good politics. Senator Feingold, for instance, when speaking on the proposed legislation to implement the Convention in the United States, was more than pleased to be aligned with this law, noting:

I believe this is a vitally important treaty, and I am thrilled that the Senate has moved so quickly to ratify it. As a direct descendent of Senator Proxmire's Foreign Corrupt Practices Act, it represents the best of a long Wisconsin tradition of good government and ethics, and I am proud to have been a part of the Senate's ratification of this effort. ${ }^{19}$

An editorial in the Washington Post aptly put the situation thus:

It's not every day that Congress has an opportunity to pass legislation that has no down side whatsoever; that can only help the United States and U.S. businesses; that fulfills a demand Congress itself made 10 years ago; and that - perhaps rarest of all — has the ardent support of both President Clinton and Sen. Jesse Helms. The House has such an opportunity now...(Washington Post: 1998b).

\section{Conclusion}

\footnotetext{
${ }^{19}$ Congressional Record July 31, 1998, S9669.
} 
Foreign policy analysts have long recognized that, rather than the outcome of purposive choices made by value-maximizing actors on the basis of material interest, foreign policies can sometimes be the product of 'muddling through' standard operating procedures, the outcome of complex processes of bureaucratic bargaining, or the result of cognitive errors on the part of decision-makers (Allison 1969; see also Jervis 1976). Yet only recently have scholars begun to apply the insights of Constructivism from the broader field of IR to foreign policy and to demonstrate the importance of ideas, metaphor, identity, rhetoric, and norms in the analysis of foreign policy (FPA) (Flanik 2011; see also Bratberg 2011; Browning 2008; Waldorf 2010; Widmaier 2007; Fibbert 2006; and Houghton 2007).

In applying a Constructivist lens to the analysis of American foreign economic policy on bribery and corruption this article supports the fruitfulness of Constructivist FPA and adds insights from the theory of legal reasoning to explain the mechanism by which powerful social norms can exert their force on foreign policy. Firm preferences and material interests are insufficient to explain the course of U.S policy on foreign bribery since 1977. Due to the legacy of the Watergate scandal in the 1970s, the norm of anti-corruption was highly resonant in American politics. The unilateral enactment of the FCPA counter to strategic trade interests, the failure to repeal despite a decade of lobbying by powerful business groups, and the shift by business groups to support the internationalization of the FCPA through the OECD in the 1990s are all best explained with reference to the domestic political context of anti-corruption norm resonance. Although supporting the practice of bribery in international business as its competitors did would have promoted American strategic trade interests, strong resonance of the anticorruption norm in U.S. politics made public defense of such a policy politically untenable.

Recent trends in the enforcement of the FCPA, now in the context of the international regime of anti-corruption, are further evidence of the lasting impact of American anti-corruption norm resonance not just on the course of American politics, but on the course of world politics and global governance as well. Further research on the immediate underlying motivations of recent patterns of US FCPA enforcement is needed; the underlying force of the anti-corruption norm that initially propelled the FCPA to such 
Easier Done Than Said

GUTTERMAN

prominence should not be overlooked in any explanation of contemporary US policy on foreign bribery and corruption. 


\section{References}

Allison, Graham T. (1969) Conceptual Models and the Cuban Missile Crisis. The American Political Science Review 63 (3): 689-718.

Auerbach, Stuart. (1983) Antibribery Law Changes Mulled. Washington Post, May 3: D7.

Auerbach, Stuart. (1986) Business Won’t Fight Trade Bill: Organizations rebuff plea from the Administration; Business groups urge support of a trade bill. Washington Post, June 12: E1.

Berry, John. M. (1981) Senate Backs Softening of Bribery Act. Washington Post, November 24: C8.

Blustein, Paul. (1997a) Fight Looms over Foreign Bribery: France, Germany blocking efforts to outlaw practice, U.S. officials say. Washington Post, May 9: A22.

Blustein, Paul. (1997b) Pact to Bar Bribery Is Reached: Major nations agree to U.S. request. Washington Post, May 24: F1.

Boulton, David. (1978) The Lockheed Papers. London: Jonathan Cape.

Brademas, John and Fritz Heiman. (1998) Tackling International Corruption: No Longer Taboo. Foreign Affairs 77 (5): 17-23.

Bratberg, Oeiving. (2011) Ideas, tradition and norm entrepreneurs: retracing guiding principles of foreign policy in Blair and Chirac's speeches on Iraq. Review of International Studies 37 (1) (Jan): 327-348.

Brennan, Bartley A. (1990) The Foreign Corrupt Practices Act Amendments of 1988: Death of a Law. N.C.J. International Law and Commercial Regulation 15: 22947.

Brock, Bill. (1981) No Wonder No Exports. Washington Post, May 20: A23.

Browning, Christopher S. (2008) Constructivism, Narrative and Foreign Policy Analysis: A Case Study of Finland. Bern: Peter Lang.

Campbell, John. (1998) Institutional Analysis and the Role of Ideas in Political Economy. Theory and Society 27 (3): 377-409.

Cattan, Thomas and Joshua Chaffin. (2003) Bribery Has Long Been Used to Land International Contracts: New laws will make that tougher. Financial Times, May 8.

Chapman, Bruce. (1998) More Easily Done Than Said: Rules, Reason and Rational Choice. Oxford Journal of Legal Studies: 293-329.

Cragg, Wesley and William Woof. (2001) Legislating against Corruption in International Markets: The story of the US Foreign Corrupt Practices Act. In The Political Economy of Corruption, edited by Arvind K. Jain. London: Routledge. 
Elliot, Kimberley Ann. (2002) Corruption as an International Policy Problem. In Political Corruption: Concepts and Contexts, edited by Arnold J. Heidenheimer and Michael Johnston. New Brunswick, NJ: Transaction.

Emery, Fred. (1994) Watergate: The Corruption of American Politics and the Fall of Richard Nixon. New York: Touchstone.

Fearon, James and Alexander Wendt. (2002) Rationalism v. Constructivism: A Skeptical View. In Handbook of International Relations edited by Walter Carlsnaes, Thomas Risse, and Beth A. Simmons, 52-72. London: Sage.

Flanik, William. (2011) Bringing FPA Back Home: Cognition, Constructivism, and Conceptual Metaphor. Foreign Policy Analysis 7 (4): 423-446.

Flibbert, Andrew. (2006) The road to Baghdad: Ideas and intellectuals in explanations of the Iraq War. Security Studies 15 (2) (Jul): 310-352.

George, Barbara Crutchfield, Kathleen A. Lacey and Jutta Birmele. (2000) The 1998 OECD Convention: An Impetus for Worldwide Changes in Attitudes Toward Corruption in Business Transaction. American Business Law Journal 37 (3): 485525.

Goldschlager, Seth. (1997) Getting Out From Under the Table. Washington Post, July 14: A19.

Hamilton, Martha M. (1981a) Corruption Law Changes Backed: SEC’s Shad favors changing Foreign Corruption Act. Washington Post, June 17: D7.

Hamilton, Martha M. (1981b) Past SEC Head: Don’t gut bribe law: Past SEC head calls bribe law changes gutting. Washington Post, July 25: D7-8.

Hamilton, Martha M. (1981c) Panel Backs Shift in Law against Bribery Abroad. Washington Post, September 17: D23.

Hamilton, Martha M. (1981d) Corrupt Practices Act Changes Urged. Washington Post, March 5: B10.

Hamilton, Martha M. (1981e) Hill Told Bribe Law Suspension Would Boost Worldwide Pact. Washington Post, May 22: D1.

Hamilton, Martha M. (1981f) Reagan Requests Changes in Corrupt Practices Act. Washington Post, May 21: B1.

Heymann, Philip B. (1981) Opening Doors for Bribery Abroad. Washington Post, May 27: A19.

Houghton, David Patrick. (2007) Reinvigorating the Study of Foreign Policy Decisionmaking: Toward a Constructivist Approach. Foreign Policy Analysis 3 (1) (January): 24-45.

Hurd, Ian. (2008) Constructivism. In Oxford Handbook of International Relations, edited by Christian Reus-Smit and Duncan Snidal. Oxford: Oxford University Press.

Jervis, Robert. (1976) Perception and Misperception in International Politics. Princeton: Princeton University Press. 
Katzenstein, Peter J., Ed. (1996) The Culture of National Security: Norms and Identity in World Politics. New York: Columbia University Press.

Klich, Agnieszka. (1996) Bribery in Economies in Transition: The Foreign Corrupt Practices Act. Stanford Journal of International Law 32: 121-47.

Kramer, Larry. (1979) Panel Has Second Thoughts about Overseas Bribery. Washington Post, June 15: C7.

Lashbrooke, E.C. Jr. (1979) The Foreign Corrupt Practices Act: A Unilateral Solution to an International Problem. Cornell International Law Journal 12 (2).

Legro, J. (2005) Rethinking the World: Great Power Strategies and International Order. Ithaca, NY: Cornell University Press.

Lissakers, Karin. (1988) Don’t Help Bribery Make a Comeback. Washington Post, July 3: C7.

Longbardi, Laura E. (1987) Reviewing the Situation: What is to be done with the Foreign Corrupt Practices Act? Vanderbilt Journal of International Law 20: 431-94.

Mackenzie, G. Calvin, and Michael Hafkin. (2002) Scandal Proof: Do Ethics Law Make Government Ethical? Washington, DC: Brookings Institution.

March, James G. and Johan P. Olson. (1998) The Institutional Dynamics of International Political Orders. International Organization 52 (4): 943-69.

Marcuss, Stanley J. and Seth Goldschlager. (1997) An Uneven International Playing Field. Washington Post, December 17: A25.

Mauro, Paolo. (1996) The Effects of Corruption on Growth, Investment, and Government Expenditure. IMF Working Paper 96/98. Washington, DC: IMF.

Milliet-Einbinder, Martine. (2000) Writing Off Tax Deductibility. OECD Observer, May 26. Available at http://www.oecdobserver.org/news/fullstory.php/aid/245 (Accessed March 9, 2012).

Mintz, Morton. (1987) Hill Considers Changing Law on Foreign Bribery; House, Senate differ on Act. Washington Post, October 25: H6.

Mintz, Morton. (1988) Conferees Make Progress on Corrupt Practices Act. Washington Post, 24 March 24: B3.

Morgan, Dan. (1979) Executives Say Bribe Law Costs U.S. Companies Business. Washington Post, March 10: A20.

Neild, Robert. (2002) Public Corruption: The Dark Side of Social Evolution. London: Anthem Press.

Noonan, John T. Jr. (1984) Bribes. New York: Macmillan.

Pastin, Mark and Michael Hooker. (1984) Ethics and the Foreign Corrupt Practices Act. In Business Ethics: Readings and Cases in Corporate Morality. Ed. W. Michael Hoffman and Jennifer Mills Moore. New York: McGraw. 
Proxmire, William. (1981) Bribery and Foreign Competition. Washington Post. June 1: A10.

Roberts, Robert N. and Marion T. Doss. (1997) From Watergate to Whitewater: The Public Integrity War. Westport, CT: Praeger.

Rose-Ackerman, Susan. (1997) Involving Multinational Lenders and Firms. In Corruption and the Global Economy, edited by Kimberley Ann Elliot. Washington, DC: Institute for International Economics.

Rubenfeld, Samuel. (2011) SEC Breaks Enforcement Record, Begins Tracking FCPA Separately. WSJ Blogs: Corruption Currents. Commentary and news about money laundering, bribery, terrorism finance, and sanctions. Available at http://blogs.wsj.com/corruption-currents/2011/11/09/sec-breaks-enforcementrecord-begins-tracking-fcpa-separately/ (Accessed November 9, 2012).

Salbu, Steven R. (1997) Bribery in the Global Market: A Critical Analysis of the Foreign Corrupt Practices Act. Washington and Lee Law Review 149: 229-87.

Seringhaus, F.H. Rolf and Philip J. Rosson. (1990) Government Export Promotion: A Global Perspective. London and New York: Routledge.

Squire Sanders. (2012) 2011 Foreign Corrupt Practices Enforcement Summaries. Squiresanders.com January 12. Available at http://www.lexology.com/library/detail.aspx?g=2f07e99a-fcca-4c7b-a9a99f6b5c3dec5a (Accessed March 9, 2012).

Transparency International. (2011) Bribe Payers Index Report 2011. Available at http://bpi.transparency.org/results/ (Accessed March 9, 2012).

U.S. General Accounting Office. (1981) Impact of Foreign Corrupt Practices Act on U.S. Business. Report to Congress. March 4.

U.S. House of Representatives. (1977) Unlawful Corporate Payments Act of 1977. Report No. 95-640. September 28.

U.S. Senate. (1976) Subcommittee on Banking, Housing, and Urban Affairs, Report no. 94-1031 to accompany S.3664. July 2.

U.S. Senate. (1977) Domestic and Foreign Investment Improved Disclosure Acts of 1977 Report No. 95-114. March 28.

U.S. Senate. (1981) Committee on Banking, Housing, and Urban Affairs. Business Accounting and Foreign Trade Simplification Act. Joint Hearings before the Subcommittee on Securities and the Subcommittee on International Finance and Monetary Policy of the Committee on Banking, Housing, and Urban Affairs. On S. 708 to amend and clarify the foreign corrupt practices act of 1977. May 20 and 21, June 16, July 23 and 24, 1981. Report No. 97-18. Washington, DC: U.S. Government Printing Office.

U.S. Senate. (1998b) Convention on Combating Bribery of Foreign Public Officials in International Business Transactions. Executive Report 105-19. July 16. 
United Press International. (1986) Baldridge: Ease Rules on Bribes to Foreigners. Washington Post, June 11: G2.

Walldorf, C. (2010) Argument, institutional process, and human rights sanctions in democratic foreign policy. European journal of international relations 16 (4) (Dec): 639-662.

Walzenbach, G.P.E. (1998) Co-ordination in Context: Institutional Choices to Promote Exports. Aldershot, U.K.: Ashgate.

Washington Post. (1998a) The Anti-Bribery Treaty. Op-ed. January 16: A20.

Washington Post. (1998b) A Vote against Bribes. Editorial. October 7: A20.

Washington Post. (1998c) A Treaty against Bribes. Editorial. May 10: C6.

Widmaier, Wesley. (2007) Constructing foreign policy crises: Interpretive leadership in the Cold War and war on terrorism. International studies quarterly 51 (4) (Dec): 779-794.

Williams, Robert. (1995) Private Interests and Public Office: The American Experience of Sleaze. Parliamentary Affairs 48 (4): 632-49. Reprinted in Corruption in the Developed World, edited by Robert Williams, Jonathan Moran, and Rachel Flanary. Cheltenham, U.K.: Edward Elgar, 2000.

Williams, Robert. (2003) Political Corruption in the United States. In Corruption in Contemporary Politics, edited by Martin J. Bull and James L. Newell. Houndmills, Basingstoke, U.K.: Palgrave Macmillan. 